RECOMMENDATIONS

\title{
Recommendations for the use of endoscopic lung volume reduction in South Africa: Role in the treatment of emphysema
}

\author{
C F N Koegelenberg, J Theron, K Dheda, J W Bruwer, B W Allwood, M J Vorster, F von Groote-Bidlingmaier, D-J Slebos, \\ P L Shah, F J F Herth
}

Prof. Coenie Koegelenberg is a consultant in pulmonology and critical care at Stellenbosch University and Tygerberg Academic Hospital, Tygerberg, Cape Town, South Africa, and the current chairman of Assembly on Interventional Pulmonology of the South African Thoracic Society. Dr Johan Theron is an interventional pulmonologist in private practice at Panorama Mediclinic, Cape Town, and an honorary lecturer at Stellenbosch University. Prof. Keertan Dheda is Head of the Lung Infection and Immunity Unit and the Division of Pulmonology, Department of Medicine and UCT Lung Institute, University of Cape Town and Groote Schuur Hospital, Cape Town. Dr Willie Bruwer is an interventional pulmonologist in private practice at Windhoek Mediclinic, Namibia. Dr Brian Allwood is a consultant in pulmonology and critical care, Dr Morné Vorster a senior registrar and Dr Florian von Groote-Bidlingmaier an honorary lecturer in the Division of Pulmonology, Department of Medicine, Stellenbosch University and Tygerberg Academic Hospital. Dr Dirk-Jan Slebos is a consultant in interventional pulmonology in the Department of Pulmonary Diseases, University of Groningen, University Medical Center Groningen, The Netherlands. Dr Pallav Shah is a consultant physician in respiratory medicine at Royal Brompton Hospital, London, UK. Prof. Dr. med. Felix Herth is the Director of Pulmonology and Critical Care Medicine, Thoraxklinik, University Hospital Heidelberg, Heidelberg, Germany.

Corresponding author: C F N Koegelenberg (coeniefn@sun.ac.za)

Emphysema is a very common cause of morbidity and mortality in South Africa (SA). Therapeutic options in severe emphysema are limited. Endoscopic lung volume reduction (ELVR) is increasingly being used internationally for the treatment of advanced emphysema in a subset of patients with advanced disease, aiming to obtain the same functional advantages as surgical lung volume reduction while reducing risks and costs. In addition to endobronchial valves, ELVR using endobronchial coils is now available in SA. The high cost of these interventions underscores the need for careful patient selection to best identify those who may or may not benefit from ELVR-related procedures. The Assembly on Interventional Pulmonology of the South African Thoracic Society appointed a committee comprising both local and international experts to extensively review all relevant evidence and provide advice on the use of ELVR in SA based on published evidence, expert opinion and local access to the various devices.

S Afr Med J 2015;105(10):810-815. DOI:10.7196/SAMJnew.8147

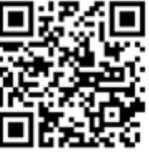

Chronic obstructive pulmonary disease (COPD) is one of the most common causes of morbidity and mortality in South Africa (SA). ${ }^{[1-3]}$ While smoking remains the most common risk factor for the development of COPD locally, long-term biomass fuel exposure, tuberculosis and HIV also contribute significantly to the disease burden ${ }^{[4]}$ In addition, poverty has been shown to be associated with an increased burden of COPD.${ }^{[5]}$ Pharmacotherapy and guidance on smoking cessation continue to form the backbone of management guidelines for COPD in SA. ${ }^{[1,6]}$

In advanced emphysema, therapeutic options are limited. Surgical lung volume reduction is known to improve functional status and mortality, but only in the subgroup of patients with predominant upper-lobe emphysema and low exercise capacity, and at the cost of high morbidity. ${ }^{[7]}$ Endoscopic lung volume reduction (ELVR) refers to bronchoscopically facilitating volume loss to improve pulmonary mechanics and compliance, ${ }^{[8,9]}$ and is now increasingly being used internationally for the treatment of advanced emphysema. The aim of ELVR is to obtain the same functional advantages as surgical lung volume reduction, with reduced risks and costs. These techniques aim to achieve regional reductions in lung volume, ${ }^{[8]}$ thereby decreasing dynamic hyperinflation, with resultant improvement in diaphragm and chest wall mechanics. In addition, endobronchial coils in particular re-tension the airway network and in so doing mechanically increase elastic recoil in the emphysematous lungs, tethering open airways and thereby preventing airway collapse. ${ }^{[10]}$

There is a growing body of evidence that certain patients with advanced emphysema benefit from ELVR, provided that a systematic approach is followed and selection criteria are met. In addition to endobronchial valves, endobronchial coils for ELVR are now available in SA. The high cost of these interventions underscores the need for careful patient selection to best identify those who may or may not benefit from ELVR-related procedures.

The Assembly on Interventional Pulmonology of the South African Thoracic Society appointed a committee comprising both local and international experts to review the evidence and provide advice on the use of ELVR in SA based on published evidence, expert opinion and local access to the devices used for ELVR. The aim is to provide SA pulmonologists with an overview of the efficacy of the various techniques and evidence for their use, and to suggest an evidencebased approach for the appropriate local use of these devices.

\section{Modalities and devices currently available in SA \\ 1.1 Unidirectional endobronchial and intrabronchial valves}

Unidirectional valves block entrance of air during inspiration, but permit exhalation of air and secretions, causing partial or complete 
lobar collapse. The valves are self-expanding devices that are implanted via a catheter introduced through the working channel of a flexible bronchoscope. ${ }^{[8]}$ Currently, Zephyr endobronchial valves (Pulmonx Inc., USA) and IBV intrabronchial valves (Olympus Respiratory America, USA) are commercially available in SA.

Zephyr valves (Fig. 1) are made of a nitinol (nickel titanium) mesh covered by silicone and contain a double silicone membrane that opens during expiration and closes during inspiration. They are available in two sizes, one for segmental $(4.0-9.0 \mathrm{~mm})$ and one for lobar bronchi $(5.5-8.5 \mathrm{~mm}) \cdot{ }^{[8]}$ IBV valves (Fig. 2) are umbrella-shaped devices made of a nitinol mesh covered by a polyurethane membrane, and available in four different sizes $(5,6,7$ and $9 \mathrm{~mm}$ )

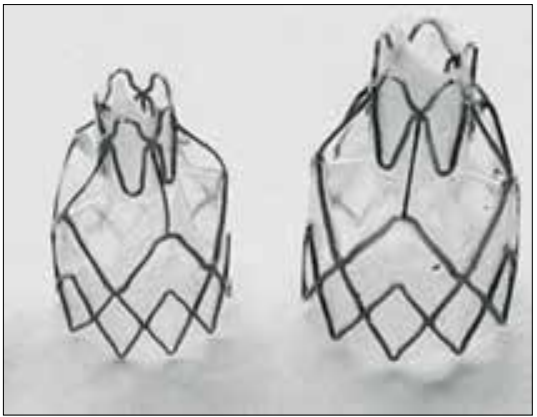

Fig. 1. Endobronchial (Zephyr) valves of varying diameters for lobar or segmental occlusion.

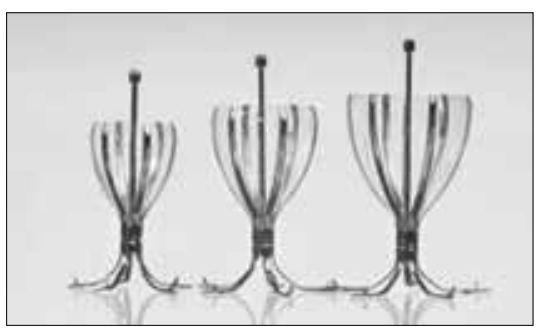

Fig. 2. Intrabronchial (IBV) valves of varying diameters.

Two major caveats for the use of valves and other bronchial blocking devices are the presence of either a homogeneous distribution of emphysema or significant collateral ventilation. ${ }^{[8]}$ The degree of heterogeneity can be judged either by visual inspection of a high-resolution chest computed tomography (HRCT) scan or with specifically designed software. Heterogeneous emphysema is denoted by a $>25 \%$ difference in emphysema score between ipsilateral upper and lower lobes, measured at a threshold of $<-950$ Hounsfield units. $^{[11]}$ In the absence of heterogeneous emphysema, bronchial blocking devices are unlikely to be successful.
Similarly, endobronchial blocking devices are unlikely to be beneficial in the presence of significant interlobar collateral ventilation. Such collateral ventilation prevents atelectasis and thereby subverts the deflating effect of the devices. The presence of incomplete fissures, seen on an HRCT scan, is considered a proxy for physiological interlobar collateral ventilation. Recent evidence suggests that if the fissures are $<75 \%$ intact, further evaluation should not be performed as collateral ventilation is always present, whereas with $>90 \%$ complete fissures, collateral ventilation is practically never present. The Chartis system is an endobronchial catheter system (Chartis Pulmonary Assessment System; Pulmonx Inc.) used to directly measure the percentage of interlobar collateral ventilation in patients with between $75 \%$ and $90 \%$ fissural integrity. ${ }^{[12]}$ The system is made up of a balloon catheter that is connected to a console and inserted into an airway via a bronchoscope. Once inflated it occludes the bronchus, preventing direct outflow of inspired air. A near-constant rate of expiratory airflow during the assessment is observed in cases with collateral ventilation, whereas a steady reduction in flow is observed in the absence of collateral ventilation. ${ }^{[12]}$

The current evidence for the use of endobronchial and intrabronchial valves is summarised in Table 1. Although numerous observational and randomised trials showed statistical benefits in respect of practically all functional parameters, minimal clinically important differences (MICDs) were significantly more likely to be observed in patients with advanced heterogeneous emphysema and no collateral ventilation and in those in whom unilateral valve placement achieved complete lobar collapse. ${ }^{[13-19]}$ The most common reported adverse events were pneumothoraces (5 - 10\%), mild haemoptysis (2 - 6\%) and exacerbations of underlying COPD (8 $40 \%)$.

The recently completed STELVIO trial provided the strongest evidence for use of valves in patients without collateral ventilation. ${ }^{[19]}$ Dutch investigators randomised 68 patients with severe heterogeneous emphysema on HRCT with visual estimation of complete or near-complete fissures to endobronchial Zephyr valve treatment $(n=34)$ or standard medical care $(n=34)$. The primary outcome measures were change in spirometric measures and 6-minute walking distance (6MWD) at 6 months. Clinical relevance was assessed relative to MICDs. At 6 months, the MICDs were attained in all parameters in the treated group compared with controls $(p<0.001$ for all endpoints).

\subsection{Coils}

Coils (RePneu; BTG Inc., USA) are nitinol devices (Fig. 3) designed to be straightened for deployment into a subsegmental airway, and thereafter to resume their preformed shape. ${ }^{[10]}$ This conformational shape change after deployment results in parenchymal retraction with volume loss, while maintaining airway patency. ${ }^{[10]}$ The device is currently available in three lengths $(100,125$ and $150 \mathrm{~mm})$ to accommodate different-sized airways. The coils are implanted via a flexible bronchoscope under general anaesthesia or conscious sedation and fluoroscopic guidance using a proprietary delivery system.

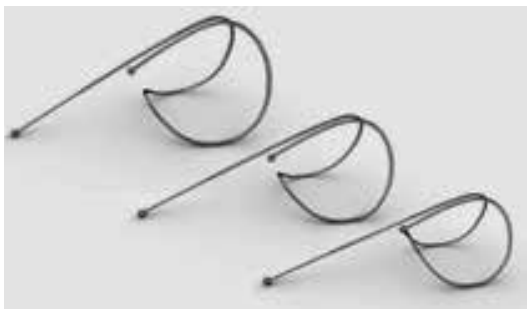

Fig. 3. Endobronchial (RePneu) coils of varying lengths.

Current evidence (Table 2) suggests that candidates with both heterogeneous and homogeneous emphysema can experience clinically significant benefit from ELVR using coils. ${ }^{[10,20-23]}$ This benefit is obtained regardless of the presence of collateral ventilation, or complete lobar collapse post insertion, but requires that no more than $75 \%$ of the total lung parenchyma is destroyed by emphysema prior to insertion. ${ }^{[11,22]}$ Approximately $75-80 \%$ of patients will experience MICDs in lung function and quality of life, while mild haemoptysis of $<5 \mathrm{~mL}(50-75 \%)$, exacerbations of COPD (5 - 12\%), mild chest discomfort (15-50\%) and infrequent pneumothoraces (3\%) are the described adverse events. ${ }^{[11,22]}$ A recent report on the 3-year follow-up data of 38 patients who underwent ELVR using coils suggested that the coil treatment was safe; no late pneumothoraces, coil migrations or unexpected adverse events occurred. ${ }^{[23]}$ Although clinical benefit declined gradually over time, at 3 years after treatment approximately $50 \%$ of patients maintained improvements in 6MWD and subjective dyspnoea, as well as quality of life scores. 
Table 1. Summary of key clinical studies that evaluated the safety and efficacy of ELVR with valves

\begin{tabular}{|c|c|c|c|c|c|}
\hline Study details & Design & $\begin{array}{l}\text { Primary efficacy } \\
\text { measures }\end{array}$ & Major outcomes & $\begin{array}{l}\text { Major adverse } \\
\text { events }\end{array}$ & Comments \\
\hline $\begin{array}{l}\text { Snell et al., }{ }^{[13]} 2003 \\
\text { Number enrolled: } 10\end{array}$ & $\begin{array}{l}\text { Case series: bilateral ELVR } \\
\text { (feasibility study) }\end{array}$ & NA & $\begin{array}{l}\text { No major change in } \\
\text { radiological findings, } \\
\text { lung function or } \\
6 \mathrm{MWD} \text {; } \mathrm{DL}_{\mathrm{CO}} \\
\text { improved from mean } \\
(\mathrm{SD}) 7.47(2.0) \text { to } \\
8.26(2.6) \mathrm{mL} / \mathrm{min} / \\
\mathrm{mmHg}(p=0.04)\end{array}$ & $\begin{array}{l}\text { No major } \\
\text { complications (at } \\
30 \text { days). Minor } \\
\text { complications } \\
\text { included } \\
\text { exacerbation of } \\
\text { COPD ( } n=3) \text {, } \\
\text { asymptomatic } \\
\text { pneumothorax } \\
(n=1) \text { and } \\
\text { pneumonia }(n=1)\end{array}$ & $\begin{array}{l}\text { Showed that ELVR with } \\
\text { valves was feasible and } \\
\text { safe, but that further } \\
\text { studies were needed } \\
\text { to explore patient } \\
\text { characteristics that } \\
\text { determine symptomatic } \\
\text { efficacy }\end{array}$ \\
\hline $\begin{array}{l}\text { Toma et al., }{ }^{[14]} 2003 \\
\text { Number enrolled: } 8\end{array}$ & $\begin{array}{l}\text { Case series: unilateral } \\
\text { ELVR (feasibility study) }\end{array}$ & NA & $\begin{array}{l}\text { Median } \mathrm{FEV}_{1} \\
\text { increased from } 0.79 \text { to } \\
1.06 \mathrm{~L}(p=0.028) \text { and } \\
\text { median } \mathrm{DL}_{\mathrm{CO}} \text { from } \\
3.05 \text { to } 3.92 \mathrm{~mL} / \mathrm{min} / \\
\mathrm{mmHg}(p=0.017)\end{array}$ & $\begin{array}{l}\text { Pneumothorax } \\
(n=2)\end{array}$ & $\begin{array}{l}\text { Acceptable short-term } \\
\text { safety }\end{array}$ \\
\hline 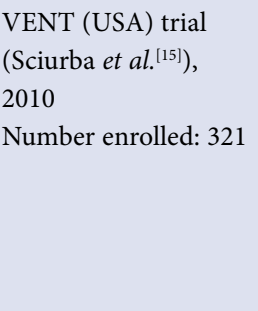 & $\begin{array}{l}\text { RCT (2:1): unilateral ELVR } \\
\text { v. standard medical care }\end{array}$ & $\begin{array}{l}\text { Changes in } \mathrm{FEV}_{1} \\
\text { and } 6 \mathrm{MWD} \text { at } 6 \\
\text { months }\end{array}$ & $\begin{array}{l}\mathrm{FEV}_{1} 1.9 \% \text { higher } \\
(p=0.007) \text { and } \\
6 \mathrm{MWD} 19.1 \mathrm{~m} \\
\text { more }(p=0.02) \text { in } \\
\text { treated group; SGRQ } \\
\text { decreased by } 3.4 \\
(p=0.04)\end{array}$ & $\begin{array}{l}\text { COPD exacerbation } \\
\text { requiring } \\
\text { hospitalisation }(7.9 \% \\
\text { v. } 1.1 \%)(p=0.03) \\
\text { and haemoptysis } \\
(6.1 \% \text { v. } 0 \%(p=0.01) \text {. } \\
\text { Pneumonia in target } \\
\text { lobe }(4.2 \%)\end{array}$ & $\begin{array}{l}\text { Greater radiographic } \\
\text { evidence of emphysema } \\
\text { heterogeneity and } \\
\text { fissure completeness } \\
\text { was associated with an } \\
\text { enhanced response to } \\
\text { treatment }\end{array}$ \\
\hline $\begin{array}{l}\text { VENT (Europe) trial } \\
\left.\text { (Herth et al. }{ }^{[16]}\right), 2012 \\
\text { Number enrolled: } 60\end{array}$ & $\begin{array}{l}\text { RCT (2:1): unilateral ELVR } \\
\text { v. standard medical care }\end{array}$ & $\begin{array}{l}\text { Changes in } \mathrm{FEV}_{1} \text {, } \\
\text { cycle ergometry } \\
\text { and SGRQ at } 6 \\
\text { months }\end{array}$ & $\begin{array}{l}\text { Mean change in } \\
\mathrm{FEV}_{1} 7.0 \% \text { v. } 0.5 \% \\
(p=0.067) ; \text { cycle } \\
\text { ergometry } 2 \mathrm{~W} \text { v. } \\
3 \mathrm{~W}(p=0.04) ; \text { SGRQ } \\
-5 \text { v. } 0.3 \text { points } \\
(p=0.047)\end{array}$ & $\begin{array}{l}\text { Pneumothorax } \\
(n=5) . \text { No } \\
\text { difference in COPD } \\
\text { exacerbation rates }\end{array}$ & $\begin{array}{l}\text { Superior clinical } \\
\text { results with computed } \\
\text { tomography suggestive } \\
\text { of complete fissures and } \\
\text { with successful lobar } \\
\text { occlusion }\end{array}$ \\
\hline $\begin{array}{l}\text { Ninane et al. }{ }^{[17]} 2012 \\
\text { Number enrolled: } 73\end{array}$ & $\begin{array}{l}\text { Sham-controlled study } \\
\text { (1:1): bilateral ELVR } \\
\text { without lobar collapse }\end{array}$ & $\begin{array}{l}\geq 4 \text {-point } \\
\text { improvement in } \\
\text { SGRQ }\end{array}$ & $\begin{array}{l}24 \% \text { responders in } \\
\text { treated group v. } 0 \% \\
\text { in control group } \\
(p=0.002)\end{array}$ & $\begin{array}{l}\text { COPD exacerbation } \\
13 \% \text { v. } 9 \%(p=0.595)\end{array}$ & $\begin{array}{l}\text { Not effective in } \\
\text { majority; major } \\
\text { finding was that } \\
\text { complications are due } \\
\text { to bronchoscopy itself } \\
\text { rather than device }\end{array}$ \\
\hline $\begin{array}{l}\text { Eberhardt et al., }{ }^{[18]} \\
2012 \\
\text { Number enrolled: } 22\end{array}$ & $\begin{array}{l}\text { RCT (1:1): bilateral } \\
\text { (incomplete occlusion ) } \\
\text { v. unilateral (for total } \\
\text { occlusion) treatment }\end{array}$ & $\begin{array}{l}\mathrm{FEV}_{1}, 6 \mathrm{MWD}, \\
\text { SGRQ }\end{array}$ & $\begin{array}{l}\mathrm{FEV}_{1} \text { improved in } \\
\text { unilaterally treated } \\
\text { group but not in the } \\
\text { other group }(21.4 \% \\
\text { v. } 0.03 \%)(p=0.002)\end{array}$ & $\begin{array}{l}\text { Respiratory } \\
\text { failure }(n=2), \\
\text { pneumothorax } \\
(n=1)\end{array}$ & $\begin{array}{l}\text { Unilateral valve } \\
\text { placement with } \\
\text { complete occlusion } \\
\text { superior to bilateral } \\
\text { partial occlusion }\end{array}$ \\
\hline $\begin{array}{l}\text { STELVIO trial } \\
\left.\text { (Klooster } \text { et al. }^{[19]}\right) \text {, } \\
2015 \\
\text { Number randomised: } \\
68\end{array}$ & $\begin{array}{l}\text { RCT (1:1): unilateral ELVR } \\
\text { (collateral ventilation } \\
\text { excluded) v. standard } \\
\text { medical care }\end{array}$ & $\begin{array}{l}\mathrm{FEV}_{1}, \mathrm{FVC}, \mathrm{RV} \\
\text { and } 6 \mathrm{MWD} \text { at } 6 \\
\text { months }\end{array}$ & $\begin{array}{l}\mathrm{FEV}_{1} 22.7 \% \text {, } \\
\text { FVC } 442 \mathrm{~mL} \text {, } \\
\mathrm{RV}-831 \mathrm{~mL} \text {, } \\
6 \mathrm{MWD} 106 \mathrm{~m} \text { and } \\
\text { SGRQ }-14.7 \text { points } \\
\text { superior in treated } \\
\text { group (all } p<0.001 \text { ) }\end{array}$ & $\begin{array}{l}\text { Pneumothorax } \\
17.6 \%\end{array}$ & $\begin{array}{l}\text { Best evidence that } \\
\text { ELVR with valves in } \\
\text { the absence of collateral } \\
\text { ventilation results } \\
\text { in statistically and } \\
\text { clinically significant } \\
\text { improvements in } \\
\text { pulmonary function, } \\
\text { exercise capacity and } \\
\text { quality of life }\end{array}$ \\
\hline
\end{tabular}


Table 2. Summary of key clinical studies that evaluated the safety and efficacy of ELVR with coils

\begin{tabular}{|c|c|c|c|c|c|}
\hline Study details & Design & Efficacy measures & Outcome & Major adverse events & Comments \\
\hline $\begin{array}{l}\text { Herth et al. },^{[10]} 2010 \\
\text { Number enrolled: } 11\end{array}$ & $\begin{array}{l}\text { Case series } \\
\text { (feasibility study) }\end{array}$ & NA & NA & $\begin{array}{l}\text { COPD exacerbations } \\
\text { (mild), no } \\
\text { pneumothorax }\end{array}$ & $\begin{array}{l}\text { ELVR with coils was } \\
\text { deemed safe and } \\
\text { feasible }\end{array}$ \\
\hline $\begin{array}{l}\text { Slebos et al, }{ }^{[20]} 2012 \\
\text { Number enrolled: } 16\end{array}$ & $\begin{array}{l}\text { Prospective cohort } \\
\text { pilot study }\end{array}$ & $\begin{array}{l}\text { SGRQ, FEV }, \text { FVC, } \\
\text { RV, 6MWD }\end{array}$ & $\begin{array}{l}\text { SGRQ improved } \\
\text { by } 14.9 \text { points (in } \\
11 \text { patients by }>4 \\
\text { points), } \mathrm{FEV}_{1} \text { by } \\
14.9 \%, \mathrm{FVC} \text { by } \\
13.4 \%, \text { RV by } 11.4 \% \\
\text { and } 6 \mathrm{MWT} \text { by } \\
84.4 \mathrm{~m}(\text { all } p<0.005)\end{array}$ & $\begin{array}{l}\text { Pneumothorax }(n=1), \\
\text { pneumonia }(n=2), \\
\text { COPD exacerbation } \\
(n=6), \text { chest pain } \\
(n=4), \text { mild }(<5 \mathrm{~mL}) \\
\text { haemoptysis }(n=21)\end{array}$ & $\begin{array}{l}\text { First study to } \\
\text { show significant } \\
\text { improvements in } \\
\text { pulmonary function, } \\
\text { exercise capacity, } \\
\text { and quality of life }\end{array}$ \\
\hline $\begin{array}{l}\text { RESET trial (Shah et al. }{ }^{[21]} \text { ), } \\
2013 \\
\text { Number enrolled: } 47\end{array}$ & $\begin{array}{l}\text { RCT (1:1): bilateral } \\
\text { ELVR v. standard } \\
\text { medical care }\end{array}$ & SGRQ & $-8.63(p=0.04)$ & $\begin{array}{l}\text { COPD exacerbation } \\
(4 \%)\end{array}$ & $\begin{array}{l}\text { Evidence of improved } \\
\text { quality of life }\end{array}$ \\
\hline $\begin{array}{l}\text { Deslee et al., }{ }^{[11]} 2014 \\
\text { Number enrolled: } 60\end{array}$ & $\begin{array}{l}\text { Prospective } \\
\text { multicentre cohort } \\
\text { trial }\end{array}$ & $\begin{array}{l}\text { SGRQ, pulmonary } \\
\text { function testing, } \\
\text { mMRC and } 6 \mathrm{MWD} \\
\text { up to } 12 \text { months }\end{array}$ & $\begin{array}{l}\Delta \text { SGRQ }-11.1 \\
\text { points, } \Delta 6 \mathrm{MWD} \\
+51.4 \mathrm{~m}, \Delta \mathrm{FEV}_{1} \\
+0.11 \mathrm{~L} \text {, and } \Delta \mathrm{RV} \\
-0.71(\text { all } p<0.01)\end{array}$ & $\begin{array}{l}\text { COPD exacerbation } \\
(6.1 \%) \text {, pneumonia } \\
(5.2 \%) \text {, pneumothorax } \\
(3.5 \%) \text {, haemoptysis } \\
(0.9 \%)\end{array}$ & $\begin{array}{l}\text { Significant } \\
\text { responses for both } \\
\text { heterogeneous } \\
\text { and homogeneous } \\
\text { emphysema }\end{array}$ \\
\hline $\begin{array}{l}\text { Klooster et al. },^{[22]} 2014 \\
\text { Number enrolled: } 10\end{array}$ & $\begin{array}{l}\text { Prospective single- } \\
\text { centre cohort trial }\end{array}$ & $\begin{array}{l}\text { Change in } 6 \mathrm{MWD} \\
\text { at } 6 \text { months }\end{array}$ & $\begin{array}{l}\text { 6MWD improved } \\
\text { from } 289 \text { to } 350 \\
\mathrm{~m}(p=0.005), \mathrm{FVC} \\
\text { from } 2.17 \text { to } 2.55 \\
\mathrm{~L} \text { ( } p=0.047), \mathrm{RV} \\
\text { from } 5.04 \text { to } 4.44 \\
\mathrm{~L} \text { ( } p=0.007) \text { and } \\
\text { SGRQ from } 63 \text { to } \\
48 \text { points }(p=0.028)\end{array}$ & $\begin{array}{l}\text { Pneumothorax } \\
(n=1) \text {, slight }(<5 \mathrm{~mL}) \\
\text { haemoptysis }(n=5), \\
\text { chest discomfort }(n=6) \text {, } \\
\text { COPD exacerbation } \\
(n=5)\end{array}$ & $\begin{array}{l}\text { The benefit of LVR } \\
\text { coil treatment is not } \\
\text { limited to patients } \\
\text { with heterogeneous } \\
\text { emphysema }\end{array}$ \\
\hline $\begin{array}{l}\text { Hartman et al., }{ }^{[23]} 2015 \\
\text { Number enrolled: } 38\end{array}$ & $\begin{array}{l}\text { Prospective single- } \\
\text { centre cohort trial }\end{array}$ & $\begin{array}{l}\text { mMRC, pulmonary } \\
\text { function testing and } \\
6 \mathrm{MWD} \text { at } 5 \text { years }\end{array}$ & $\begin{array}{l}\text { Significant } \\
\text { improvement } \\
\text { in mMRC score } \\
\text { remained, with } \\
40 \% \text { of the patients } \\
\text { reaching the } \\
6 \text { MWD MICD and } \\
59 \% \text { the SGRQ } \\
\text { MICD }\end{array}$ & $\begin{array}{l}\text { No device-related } \\
\text { complications }\end{array}$ & $\begin{array}{l}\text { Best long-term data } \\
\text { on safety of coils }\end{array}$ \\
\hline
\end{tabular}

\section{Modalities not available in SA}

\subsection{Bronchial spigots}

Watanabe Spigots (Novatech, France) have been used successfully in the management of pulmonary fistula and persistent pneumothorax with continuous air leakage. ${ }^{[24]}$ Despite many reports describing successful treatment of persistent air leaks using endobronchial Watanabe Spigots, evidence for their use in the context of ELVR for emphysema is lacking.

\subsection{Sealants}

The AeriSeal system (Aeris Therapeutics Biological, Pulmonx Inc.) uses synthetic polymeric foam to obtain atelectasis. A recent multicentre randomised controlled trial, terminated early for financial reasons, confirmed significantly improvements from baseline in lung function, dyspnoea and quality of life when compared with controls at 3 months, but the fact that $44 \%$ of treated patients experienced adverse events requiring hospitalisation (including two deaths) raised some safety concerns. ${ }^{[25]}$

\subsection{Vapour}

Bronchoscopic thermal vapour ablation (InterVapor; Uptake Medical, USA) uses high-temperature water vapour delivered into the target lung segments through a catheter with precise amount of energy, thereby inducing thermal damage resulting in permanent airway fibrosis. ${ }^{[8]}$ Although one potential advantage of this technology is that it is not influenced by interlobar collateral ventilation, it has been shown to have a relatively modest effect on lung function. ${ }^{[26,27]}$ Adverse events, particularly COPD exacerbations, are frequently observed. ${ }^{[28]}$

\subsection{Airway bypass}

The technique of airway bypass is based on the creation of extraanatomical passages between the hyperinflated lung parenchyma and larger airways. ${ }^{[8]}$ Evidence suggests that although some shortterm benefit may be achieved in patients with severe hyperinflation, pulmonary function appears to return to baseline within 3 months. ${ }^{[29-31]}$ 
3. Evaluation of candidates for potential lung volume reduction

The initial screening of potential candidates with stable disease should ideally be performed by pulmonologists, and should include an assessment of severity of dyspnoea, functional impairment, past thoracic surgery, comorbidities and smoking status.

Routine special investigations should include an HRCT scan (to estimate heterogeneity, integrity of fissures and degree of tissue destruction, and to exclude occult malignancy), full pulmonary function testing (including measurements of forced expiratory volume in 1 second, forced vital capacity, residual volume (RV), RV/total lung capacity (TLC), TLC, carbon monoxide diffusing capacity and 6MWD), arterial blood gas measurement and echocardiography (to exclude pulmonary artery pressures $>50 \mathrm{mmHg}$ ).

The general indications for and contraindications to valves and coils are summarised in Table 3. ELVR should not be offered to active smokers, patients with pulmonary hypertension, unstable cardiac pathology, active respiratory infections, a very poor exercise tolerance or no clear evidence of hyperinflation, or to patients on any type of long-term antiplatelet or anticoagulant therapy that cannot be stopped 7 days before the procedure.

Appropriate or borderline candidates should be referred to a centre with the capacity to evaluate and treat them and follow them up, including managing complications and removal of devices if required. These centres should individualise the interventions on the basis of disease phenotype (e.g. heterogeneous v. homogeneous disease), degree of tissue destruction, the presence of collateral ventilation and pulmonary impairment.

\section{Suggested approach to \\ ELVR in $\mathrm{SA}$}

There is currently no official guideline from any of the major thoracic societies and no head-to-head evidence comparing the various techniques and devices. The Assembly on Interventional Pulmonology of the SA Thoracic Society has therefore based the approach summarised in Fig. 4 on the available published evidence, availability of the devices in SA and international expert opinion.

The degree of severity of emphysema, the degree of tissue destruction, heterogeneity of the disease and the presence of collateral ventilation are all important factors in the final selection process. $^{[8]}$ The algorithm presented in Fig. 4 should not be viewed as a rigid guideline, and the clinician should still

Table 3. General indications for and contraindications to ELVR with endobronchial and intrabronchial valves and coils in patients with stable emphysema

Indications

40 - 75 years

Heterogeneous emphysema and no collateral ventilation (valves)*

Dyspnoea despite maximal medical therapy and pulmonary rehabilitation

$\mathrm{FEV}_{1} 15-45 \%$

Hyperinflation with TLC $>100 \%$ and RV $>150$ - 175\%

$\mathrm{PaCO}_{2}<6.7 \mathrm{kPa}(50 \mathrm{mmHg})$

$\mathrm{PaO}_{2}>6 \mathrm{kPa}(45 \mathrm{mmHg})$ while breathing ambient air

$6 \mathrm{MWD} \geq 140 \mathrm{~m}$ (after rehabilitation)

Contraindication

Homogeneous emphysema (valves)*

Collateral ventilation/non-intact fissures (valves) ${ }^{*}$

$>75 \%$ parenchymal destruction on HRCT (coils) ${ }^{\dagger}$

Current smoking (past 6 months)

$\mathrm{DL}_{\mathrm{CO}}<20 \%$ (relative)

Giant bullae ( $>1 / 3$ of hemithorax)

Alpha-1-antitrypsin deficiency

Previous thoracotomy, pleurodesis or chest wall deformity

Excessive sputum

Severe pulmonary hypertension $(>50 \mathrm{mmHg}$ )

Active infection

Unstable cardiac conditions

Significant pleural or interstitial changes on HRCT

Any type of antiplatelet or anticoagulant therapy that cannot be stopped for 7 days prior to procedure

$\mathrm{FEV}_{1}=$ forced expiratory volume in 1 second; TLC $=$ total lung capacity; $\mathrm{RV}=$ residual volume; $\mathrm{PaCO}_{2}=$ partial pressure of carbon dioxide; $\mathrm{PaO}_{2}=$ partial pressure of oxygen; $6 \mathrm{MWD}=6$-minute walking distance; $\mathrm{DL}_{\mathrm{cO}}=$ carbon monoxide diffusing carbon dioxide; $\mathrm{PaO}_{2}=$ partial pressure of oxygen; $6 \mathrm{M}$
capacity. ${ }^{*}$ Capacity.
${ }^{S}$ pecific for endobronchial and intrabronchial valves. 'Specific for endobronchial coils

use discretion, especially in those patients who may potentially benefit from either coils or valves. For example, patients with 25 - 75\% tissue destruction and no collateral ventilation may also benefit from valves, although the reported response rates and improvements in functional status and pulmonary function tests seem to be greater with coils. ${ }^{[7-9,16,19]}$

It is recommended that all ELVR procedures should be performed in the context of a local and/or international registry. The Assembly on Interventional Pulmonology of the SA Thoracic Society is willing to assist potential centres wanting to establish an ELVR service in terms of training and accreditation.

\section{Conclusions}

Appropriate candidates with marked hyperinflation and relatively preserved lung parenchyma are more likely to benefit from ELVR with bilateral coils, irrespective of the collateral ventilation and heterogeneity of the disease. In contrast, patients with heterogeneous disease and no collateral ventilation are more likely to benefit from unilateral ELVR with valves, aiming to achieve complete lobar collapse. A well-structured evidence-based approach to ELVR, including initial screening and subsequent referral to a specialised centre, is important to avoid inappropriate use of devices, which may be both wasteful and harmful.

Author contributions. The article was written by CFNK and JT, and extensively reviewed by KD, JWB, BWA, MJV, FvG-B, D-JS, PLS and FJFH.

Conflicts of interest. FJFH and D-JS have performed consultant work for PulmonRx, PneumRx, Uptake Medical and Aeris. The remaining authors have nothing to declare.

\footnotetext{
1. Abdool-Gaffar M, Ambaram A, Ainslie G, et al. Guideline for the management of chronic obstructive pulmonary disease -
} 2011 update. S Afr Med J 2011;101(1):63-73. 


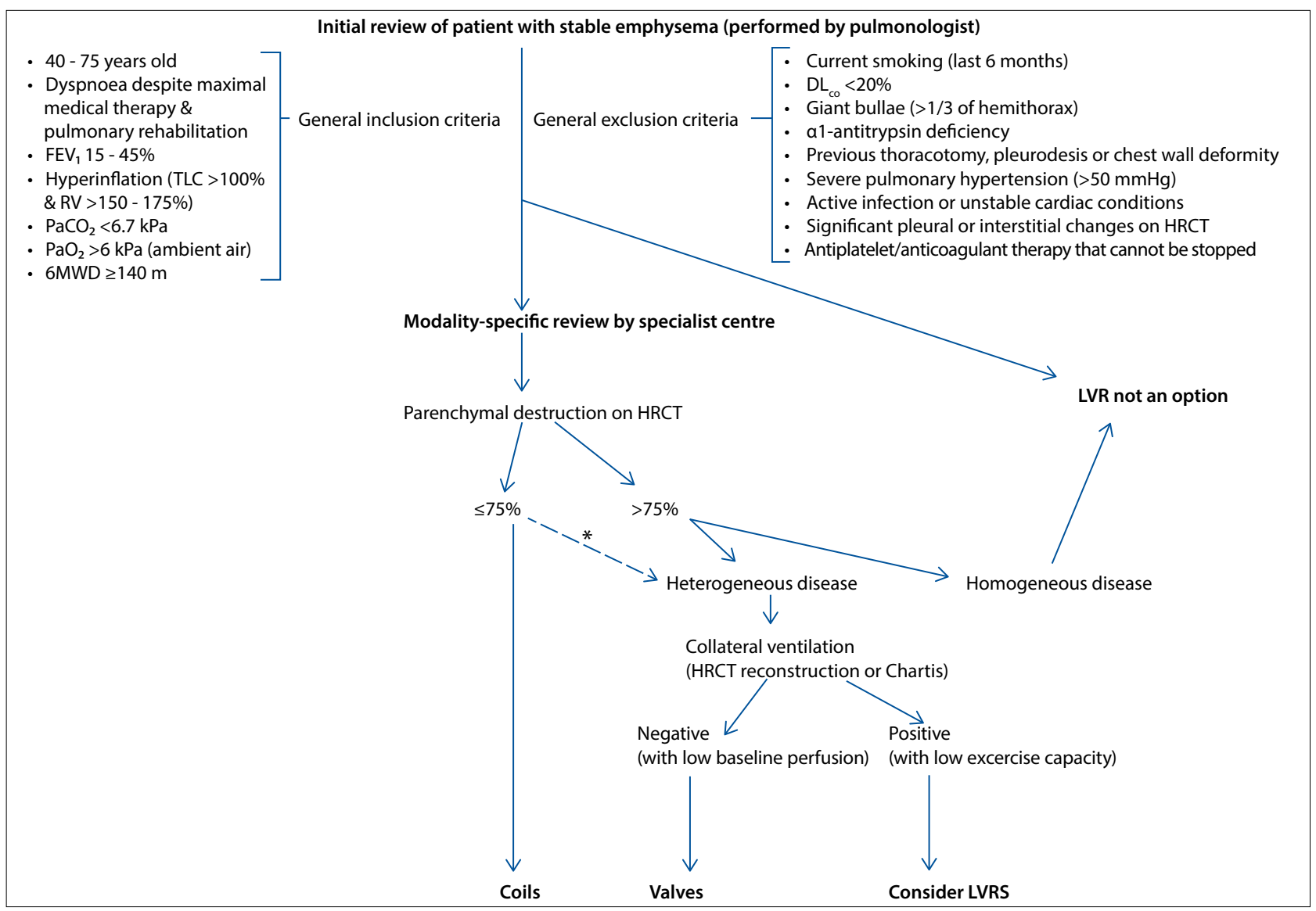

Fig. 4. Suggested approach to ELVR in SA. ( ${ }^{*}$ Patients with $25-75 \%$ of tissue destruction and no collateral circulation may also benefit from valves, although the reported response rates and improvements in functional status and pulmonary function test seem to favour ELVR with coils. LVR = lung volume reduction; LVRS = lung volume reduction surgery; $F E V_{1}=$ forced expiratory volume in 1 second; $T L C=$ total lung capacity; $R V=$ residual volume; $P a C O_{2}=$ partial pressure of carbon dioxide; $\mathrm{PaO}_{2}=$ partial pressure of oxygen; $6 \mathrm{MWD}=6$-minute walking distance; $D L_{C O}=$ carbon monoxide diffusing capacity.)

2. Koegelenberg CFN, Theron J, Bruwer JW, Allwood BW, Vorster MJ, Dheda K. Endoscopic lung volume reduction in severe emphysema. S Afr Med J 2015;105(9):1-3. [http://dx.doi.org/10.7196/ SAMJnew.8144]

3. Vorster M, Koegelenberg CFN. Lung volume reduction in chronic obstructive pulmonary disease. S Afr Med J 2015;105(9):791. [http://dx.doi.org/10.7196/SAMJnew.8427]

4. Allwood B, Myer L, Bateman E. A systematic review of the association between pulmonary tuberculosis and the development of chronic airflow obstruction in adults. Respiration 2013;86(1):76-85. [http:// dx.doi.org/10.1159/000350917]

5. Burney P, Jithoo A, Kato B, et al. Chronic obstructive pulmonary disease mortality and prevalence: The associations with smoking and poverty - a BOLD analysis. Thorax 2014;69(5):465-473. [http://dx.doi.
a org/10.1136/thoraxinl-2013-204460]

6. Van Zyl-Smit R, Allwood B, Stickells D, et al. South African tobacco smoking cessation clinical practice guideline. S Afr Med J 2013;103(11):869-876. [http:///dx.doi.org/10.7196/SAMI.7484]

7. National Emphysema Treatment Trial Group. A randomized trial comparing lung-volume-reduction surgery with medical therapy for severe emphysema. N Engl J Med 2003;348(21):2059-2073. [http:// dx.doi.org/10.1056/NEJMoa030287]

8. Gasparini S, Zuccatosta L, Bonifazi M, Bolliger CT. Bronchoscopic treatment of emphysema: State of the art. Respiration 2012;84(3):250-263. [http://dx.doi.org/10.1159/000341171]

9. Koegelenberg CFN, Slebos D-J, Shah PL, et al. Time for the global rollout of endoscopic lung volume reduction. Respiration 2015 (in press).

10. Herth FJF, Eberhard R, Gompelmann D, Slebos D-J, Ernst A. Bronchoscopic lung volume reduction with a dedicated coil: A clinical pilot study. Ther Adv Respir Dis 2010;4(4):225-231. [http://dx.doi. org/10.1177/1753465810368553]

11. Deslee G, Klooster K, Hetzel M, et al. Lung volume reduction coil treatment for patients with severe emphysema: A European multicentre trial. Thorax 2014;69(11):980-986. [http://dx.doi.org/10.1136/ emphysema: A European
thoraxjnl-2014-205221]

12. Schuhmann M, Raffy P, Yin Y, et al. CT predictors of response to endobronchial valve lung reduction treatment: Comparison with Chartis. Am J Respir Crit Care Med 2015;191(7):767-774. [http://dx.doi. org/10.1164/rccm.201407-1205OC]

13. Snell G, Holsworth L, Borrill Z, et al. The potential for bronchoscopic lung volume reduction using bronchial prostheses: A pilot study. Chest 2003;124(3):1073-1080. [http://dx.doi.org/10.1378/chest.124.3.1073]

14. Toma T, Hopkinson N, Hillier J, et al. Bronchoscopic volume reduction with valve implants in patients with severe emphysema. Lancet 2003;361(9361):931-933. [http://dx.doi.org/10.1016/S01406736(03)12762-6]

15. Sciurba FC, Ernst A, Herth FJF, et al. A randomized study of endobronchial valves for advanced emphysema. N Engl J Med 2010;363(13):1233-1244. [http://dx.doi.org/10.1056/NEJMoa0900928]

16. Herth FJF, Noppen M, Valipour A, et al. Efficacy predictors of lung volume reduction with Zephyr valves in a European cohort. Eur Respir J 2012;39(6):1334-1342. [http://dx.doi. org/10.1183/09031936.00161611]

17. Ninane V, Geltner C, Bezzi M, et al. Multicentre European study for the treatment of advanced emphysema with bronchial valves. Eur Respir J 2012;39(6):1319-1325. [http://dx.doi. org/10.1183/09031936.00019711]
18. Eberhardt R, Gompelmann D, Schuhmann M, et al. Complete unilateral vs partial bilateral endoscopic lung volume reduction in patients with bilateral lung emphysema. Chest 2012;142(4):900-908. [http:// dx.doi.org/10.1378/chest.11-2886

19. Klooster K, ten Hacken N, Hartman J, Kerstjens H, van Rikxoort E, Slebos D. Endobronchial valve treatment versus standard medical care in patients with emphysema without interlobar collateral ventilation (the STELVIO-Trial). Am J Respir Crit Care Med 2015;191(9):A6312.

20. Slebos DJ, Klooster K, Ernst A, Herth FJF, Kerstjens HM. Bronchoscopic lung volume reduction coil treatment of patients with severe heterogeneous emphysema. Chest 2012;142(3):574-582. [http:// treatment of patients with severe
dx.doi.org/10.1378/chest.11-0730]

21. Shah PL, Zoumot Z, Singh S, et al. Endobronchial coils for the treatment of severe emphysema with hyperinflation (RESET): A randomised controlled trial. Lancet Respir Med 2013;1(3):233-240. [http:// dx.doi.org/10.1016/S2213-2600(13)70047-X]

22. Klooster K, ten Hacken NHT, Franz I, Kerstjens HA, van Rikxoort EM, Slebos D-J. Lung volume reduction coil treatment in chronic obstructive pulmonary disease patients with homogeneous emphysema: $A$ prospective feasibility trial. Respiration 2014;88(2):116-125. [http://dx.doi.org/10.1159/000362522]

23. Hartman J, Klooster K, Gortzak K, ten Hacken N, Slebos D. Long-term follow-up after bronchoscopic lung volume reduction treatment with coils in patients with severe emphysema. Respirolog 2015;20(2):319-326. [http://dx.doi.org/10.1111/resp.12435]

24. Watanabe Y, Matsuo K, Tamaoki A, Komoto R, Hiraki S. Bronchial occlusion with endobronchial Watanabe spigot. J Bronchology Interv Pulmonol 2003;10(4):264-267. [http://dx.doi.org/10.1097/00128594200310000-00005]

25. Come C, Kramer M, Dransfield M, et al. A randomised trial of lung sealant versus medical therapy for advanced emphysema. Eur Respir J 2015:46(3):651-662. [http://dx.doi.org/10.1183/09031936.00205614] 26. Snell G, Hopkins P, Westall G. Holsworth L Carle A, Williams T A feasibility and safety study of be 1998. [http://dx.doi.org/10.1016/j.athoracsur.2009.06.038]

al. Bronchoscopic thermal vapour ablation therapy in the management of heterogeneous emphysema. Eur Respir J 2012;39(6):1326-1333. [http://dx.doi. org $/ 10.1183 / 09031936.00092411]$

28. Bandyopadhyay S, Henne E, Gupta A, et al. Segmental approach to lung volume reduction therapy for emphysema patients. Respiration 2015;89(1):76-81. [http://dx.doi.org/10.1159/000369036]

29. Choong C, Macklem P, Pierce J, et al. Airway bypass improves the mechanical properties of explanted emphysematous lungs. Am J Respir Crit Care Med 2008;178(9):902-905. [http://dx.doi.org/10.1164/ rccm.200712-1832OC]

30. Cardoso P, Snell G, Hopkins P, et al. Clinical application of airway bypass with paclitaxel-eluting stents Early results. J Thorac Cardiovasc Surg 2007;134(4):974-981. [http://dx.doi.org/10.1016/j.jtcvs.2007.05.040]

31. Shah P, Slebos D, Cardoso P, et al. Bronchoscopic lung-volume reduction with Exhale airway stents for emphysema (EASE trial): Randomised, sham-controlled, multicentre trial. Lancet 2011:378(9795):9971005. [http://dx.doi.org/10.1016/S0140-6736(11)61050-7]

Accepted 1 July 2015 